\title{
No Oscar for the Oscar? Behind Hollywood's Walk of Greed
}

\author{
ELIZABETH CASTALDO LUNDEN, Stockholm University
}

\begin{abstract}
In 1966 the popular interest in the Academy Awards propelled Paramount Pictures to produce The Oscar (Embassy Pictures-Paramount Pictures, 1966), a film based on the homonymous novel by Richard Sale. The Oscar tells the story of an unscrupulous actor willing to do anything in his power to obtain the golden statuette, regardless of whom he has to take down along the way. Building up on fantasies of social mobility, we see the protagonist (Frankie) display his vanity, arrogance and greed to create a less than likeable character whose only hope to put his career back on track lies in obtaining the precious statuette.
\end{abstract}

The movie intends to be a sneak peek behind the scenes of the biggest award ceremony, but also behind the lifestyle of the Hollywood elites, their glory and their misery as part of the Hollywood disposal machinery. Despite not being financed or officially supported by the Academy, the film intertwines elements of fiction and reality by using real footage of the event, and featuring several contemporary representatives of the movie industry such as Edith Head, Hedda Hopper, Frank and Nancy Sinatra, playing cameo roles, adding up to the intertextual capacities of the story. Head's participation was particularly exploited for the promotion of the film, taking advantage of her position at Paramount, her status as a multiple winner, and her role as a fashion consultant for the Academy Awards. This paper is an analytical account of the film's production process. Through a close look to its publicity, it will unravel how the studios relied on the awards, and all possible inter-textual capacities to promote the film, despite the Academy's distancing from the project.

\section{KEYWORDS}

The Oscar; Epiphenomena; Academy Awards; Edith Head; Fashion; Film; Hollywood; History; Marketing; Public Relations strategies. 
In her interpretation of epiphenomena, Barbara Klinger focuses on the operational system working around films, and the ways in which fragments of the text travel through satellite discourses such as marketing, public relations, and, even beyond, through appropriations by popular culture. The goal of these epiphenomena is not related to coherent interpretations of the film, but rather "to produce multiple avenues of access to the text that will make the film resonate as extensively as possible in the social sphere in order to maximize its audience."1 In such process, specific aspects of the text are highlighted, and even decontextualized to maximize profit, regardless of their overall narrative. Her argument lays in the inter-textual agencies within mass culture that work to structure reception beyond textual boundaries. Furthermore, she proposes to examine these digressions in order to understand the dynamics between social spectators and mainstream films.

By the mid 1960s, popular interest in the Academy Awards propelled Embassy Pictures Corporation and Paramount Pictures to co-produce The Oscar (Embassy/Paramount Pictures, 1966). The film — based on the homonymous novel by Richard Sale - tells the story of an unscrupulous actor willing to do anything in his power to obtain the golden statuette, regardless of whom he has to take down along the way. Frankie Fane-interpreted by Stephen Boyd - displays vanity, arrogance, and greed, creating a less than likable character whose only hope to put his career back on track lies in obtaining the coveted statuette. Building up on fantasies of social mobility, the movie invites audiences behind the scenes of the biggest award ceremony in the world, but also behind the lifestyle of the Hollywood elites, their glory and their misery as part of Hollywood's disposal machinery.

The Oscar can be considered a clear-cut example of epiphenomena at work in two distinct manners. Firstly, the film relies on its association to the golden award to maximize audience's interest, regardless of its compounded role in the narrative. Secondly, and risking to stretch Klinger's definition, the film can also be considered an involuntary epiphenomenon spiraling off from the Academy Awards themselves. Despite not being a film, the ceremony was already a well-established media event, and consequently functioning as a text through its mediatization. Therefore, The Oscar can be perceived as an appropriation of a digressive or fractured narrative triggered by the event's place in popular culture.

Arguably, The Oscar's production was propelled by a wish to capitalize on the Academy Awards' prestige, at a time when Hollywood's self-absorbed narratives were in vogue. This paper will unravel how the studios relied on the Academy Awards, and all possible intertextual capacities to promote the film, despite the Academy's distancing from the project. In addition, I will present how the parties involved catered to their personal interests through their association with the film, through sumptuous cachets, self-promotion for parallel projects or, even, personal shopping sprees. In this historical negotiation of the film's production, this article will begin by describing early instances of the project such as the interest in adapting the novel, and the producers' negotiations with the Academy on the use of the Oscar's trademark. Secondly, it will briefly look at how the Academy Awards were used in the film's narrative, followed by how contemporary Hollywood figures were casted in cameo roles to add up to its inter-textual capacities, by blurring the boundaries between fiction and reality. Finally, it will delve into the promotional practices that took advantage of legal grey zones to capitalize on the association to the ceremony, with special emphasis on

\footnotetext{
${ }^{1}$ Barbara Klinger, "Digressions at the Cinema: Reception and Mass Culture," Cinema Journal 28, no. 4 (Summer, 1989): 10.
} 
the role of Paramount's emblematic costume designer, Edith Head.

\title{
Let's Have THE Talk
}

Two months before its publication, in 1963, Paramount received the first proposal for turning the novel into film. Predicting the potential of its thematic, the submitted synopsis described: "The annual Oscar Awards is a target of considerable skullduggery and lurid melodrama in this novel [...] With the entire emphasis on sensationalism, the book should do well, especially in the paperback field." 2 John Boswell-Paramount's assigned readerspeculated: "Obviously this is going out from the publishers as a sexy expose of, yet again, sinful Hollywood in general and the manipulation of Academy voters and voters in particular; as such it will probably have a fair sale in hard-back and an excellent sale in paper-back. It's a trashy story, though, with a monumentally uninteresting and unbelievable heel for hero."3 Notwithstanding this assessment, Howard Koch, Paramount's head of film production, was on board by November $6^{\text {th }}, 1964$, and the project kicked off

Several reviews focused on how the novel explores the truculent Oscar campaigning in greater detail than the film. In that sense, the adaptation seemed to cautiously avoid any potential conflict with the Academy, for casting suspicion upon its integrity. In comparative analysis, an article from The Morning Telegraph illustrated:

\begin{abstract}
Those who recall the book may remember that the original author at least attempted an exposé, so to speak of the conniving, chicanery, deception and double dealing supposedly playing such a large part in the awarding of those little golden statuettes every spring. In the film, however, 'The Oscar' is not so much a story of the Oscar as it is of one outrageously despicable heel, an actor who is nominated for an award and stakes his whole career on winning it. 4
\end{abstract}

However, it would be misreading to imply that the novel casts suspicions of direct corruption related to the Academy's balloting process. In a conversation between Frankie and the private detective, they clearly discard any possibility of bribery to ensure a winning. ${ }^{5}$ The focus of the campaign, just like in the film, is directed towards manipulating the sentiments of the voters through several strategies. The different approach between these texts-novel and film-lies in their presentation of Hollywood. Frankie's character is constructed in a more villainous manner for the screen version, focusing all negative attitudes on him rather than in synergy with the industry he belongs to. Hollywood is a tough place, and no one is presented in such a binary way in the novel. Critics manifested their discomfort with the adaptation, insinuating it served the interest of the Hollywood lobby by reducing its sensationalism in its association to the coveted award. Even though the extent of the adaptation might have worked in its intention to boost an uncritical vision of Hollywood, it also raises the question behind the reason for including a reference to the awards in the first place. In other words, Hollywood can be self-critical only to a certain extent without jeopardizing its integrity, at least in this case.

\footnotetext{
${ }^{2}$ Synopsis of a new story submitted for consideration by Paramount Pictures, August 7, 1963. Production files for The Oscar, Special Collections, Margaret Herrick Library.

${ }^{3}$ Feedback reading for submission by John Boswell. Production files for The Oscar, Special Collections, Margaret Herrick Library.

${ }^{4}$ Leo Mishkin,“'The Oscar' Serves as Buildup,” The Morning Telegraph, March 5, 1966.

${ }^{5}$ Richard Sale, The Oscar (New York: Simon and Schuster, 1963), 89.
} 
Historically, the Academy has been cautions about the use of their trademark and imagery, not least from its precious symbol, the Oscar. Hence, copyright disclaimer during the titles was required, stating that 'the Academy Award 'Oscar' statuettes used in this picture by special permission of the Academy of Motion Pictures Arts and Sciences, copyright owners." Producer and screenwriter Clarence Greene took on the negotiations with Margaret Herrick for the appearance of Oscar in the film specifically, and to explore the Academy's position regarding the project in general. In her letter from June 2, 1965, Herrick assertively delimited the potential use of the trademark by specifying that Oscar could not be ever used for publicity or advertising purposes related to the film. ${ }^{7}$ From then on, the producers walked a thin line of diplomacy, getting as close to Oscar as they could without rattling the Academy. The producers ambiguous declarations to the press could be read both as a statement of diplomacy or as an insinuation that the institution was, in fact, being a part of the process: "The Academy has been a terrific help, once they read the script and saw we are treating the subject with integrity." 8 No official or unofficial joint venture came out from these negotiations or statements. In short, after passing the official consultations regarding legal matters and diplomatic warnings, there was no further involvement with the film from the Academy.

\section{Oscar: Ready for its Close Up}

The Academy Awards could be said to frame the film, literally, insofar as scenes at the ceremony open and close its narrative. The main titles run for 2 minutes and 24 seconds, and features superimposed stock footage from the 1965 ceremony, showing the exterior of the Santa Monica Civic Auditorium. The pan shots show the giant marquee announcing: " $37^{\text {th }}$ Annual Academy Awards" and "Academy of Motion Pictures Arts and Sciences" written on it. Expensive cars passing, valet parking staff waving at them, bleachers full of screaming fans, the red carpet, all merge into the film's reconstruction of the ceremony, by cutting to Frankie Fane's arrival. He descends from his vehicle and is greeted on the red carpet for the obligatory interview. The magnificent entrance was modestly reproduced for close-up shots intercalated with the stock footage. Staging the venue's exteriors took four days, at a cost of $\$ 2,509 .{ }^{9}$ In addition, a cast of 91 extras played for the illusion, for a total cost of $\$ 3,659 .{ }^{10}$

\footnotetext{
${ }^{6}$ Opening titles, The Oscar (Embassy Pictures, 1966).

${ }^{7}$ This letter has not been found for this paper, yet her statements derive from a letter answering hers present in the Production files for The Oscar, Special Collections, Margaret Herrick Library.

${ }^{8}$ Phillip K. Scheuer, “A Behind-Scenes View of What Makes 'Oscar' Run,” Los Angeles Times, September 2, 1965.

${ }^{9}$ Set construction work order, July 27, 1965. Production files for The Oscar, Special Collections. Margaret Herrick Library.

To recreate Frankie's arrival, the set designers required:

- 600 Sq. Ft. Plus 6' stock beds and steel platforms, no finish.

- $\quad 336$ Sq. Ft. plus 8' wood frame \& butted 4X8 plywood wall, paint muslin.

- 600 Sq. Ft. new wood ramp plus 8', no finish.

- $\quad 2240 \mathrm{Sq}$. Ft. red carpet in the street.

- $\quad 28$ Lin. Fit, 2 strand white rope and $54 \times 4$ wood posts \& wood plates, paint.

- 40 Lin. Ft. 3 row plank seats, no finish.

- $\quad$ Allowance to spray street and pain lines and arrow.
} 
The use of intertwined stock images of the Academy Awards' ceremony is not a minor detail form a legal and a symbolic standpoint. Stock footage served as a smart solution for adding Oscar-related material, while avoiding legal impediments. Paramount bought the color stock footage from Spotlight Production, INC. in Beverly Hills, with a check for \$1,158.46 sent to its president, Samuel D. Berns. As a result, the production companies transferred any potential legal conflicts to the company that granted the rights for this material. ${ }^{11}$ Despite being cleared from any legal impediments, Greene wrote to Herrick asking for permission to shoot Oscar for a scene, taking the opportunity to politely inform her about the purchased images, in a letter from November 22, 1965 stating:

While I do not think photographing the 'Oscar' for the main title card comes under Subdivision 2) of your letter dated June 2, 1965, which has to do with publicity and advertising, I feel we should still get your permission before proceeding. I have enclosed the sketch of what we have in mind. We would appreciate an early reply, as we will not photograph the title card until we hear from you. [...]

By this time I am convinced that every possible precaution has been taken, and the 'Oscar': will not in any way ever be used for publicity or advertising purposes. Russ and I believe that every single person involved has by now been briefed thoroughly. ${ }^{12}$

Greene informs Herrick, yet he does not open for discussions about the material. Having passed the test, the production flirted with the promotional usage of the trademark close enough to take advantage of it while keeping it safely away from the legal radar.

As previously mentioned, the ceremony serves as the story's opening and closing frame. In addition to this, the award, and its symbolic value, is brought up in several conversations towards the end of the film, when Frankie's career is already in decline. It is important to briefly summarize these passages, in order to ponder upon what audiences were encountering in the film as opposed to the generated expectations created through the promotional campaigns.

Once inside the crowded auditorium, the only empty seat in a fully packed venue is next to Frankie. It stands as a signifier for the character's loneliness, giving a snapshot of where greed and ambition has lead him. Hymie - his closes friend and publicist-stares at him, while the crowd is riveted to Bob Hope's opening act. His voiceover opens the storytelling with a monologue emphasizing the importance of the Oscars as the highest rung of the Hollywood ladder. The scene dissolves into a flashback that narrates the events in straight storyline until arriving back to the ceremony, right before the announcing of the award for best actor. No further connection to the Oscar or the Academy is made, besides a few

${ }^{10}$ Total in salaries of $\$ 2,887$. Additional cost for fittings and other technical requirements associated to the extras' performance that day. Production files for The Oscar. Special collections, Margaret Herrick Library. Role requests:

1Commentator, 1 actress, 1 photographer, 10 men and 10 women dressed to attend the ceremony, 20 men and women on the streets, 30 men and women for the bleachers, 5 young men, 5 young girls, 4 ushers, and 4 policemen.

${ }^{11}$ Receipt for payment. Production files for The Oscar. Special collections, Margaret Herrick Library.

${ }^{12}$ Letter from Clarence Greene to Margaret Herrick, November 22, 1965. Production files for The Oscar, Special Collections, Margaret Herrick Library. 
references towards the final 35 minutes of the film, after he is nominated. ${ }^{13}$ In contrast, the novel starts with Frankie's nomination, and builds up chronologically on the campaign leading to the ceremony. ${ }^{14}$

As said, the Oscar reappears once Frankie's career is about to crumble. Interestingly, the film could stand as a story about the rise to and fall from fame, without any association to the Academy Awards, by eliminating the opening sequence, and the final 35 minutes. The story settles for an additional lap only to include the Oscar in the narrative, adding charm and marketing potential to the product. Direct references to the award are made in Frankie's reflection about winning an Oscar as the only ticket back into his career, during a conversation with Hymie. The staging of the press conference also opens up for Oscar-talk when a journalist asks about how the scandal could benefit his chances of winning. Disappointed by her husband's behavior, Else Sommers' character yells at him during their break-up: "I hope your Oscar keeps you warm at night." Yet, the most resonating conversation about the precious statuette as an honorable and untouchable emblem of Hollywood comes from the dialogue between Frankie and the studio's president-Kenneth Regan-during a party to celebrate his nomination. In a man to man talk, Regan express his despise for the nominee, making clear that he is throwing the party for protocollary reasons only, and reminding him that "the Oscars mean a great deal to me, and to many of us in the industry. They are a symbol we don't like to see them tarnished." 15 Regan is nominally representing his studio-Paramount - in the nomination. Thus, he is blunt in his position. He is standing on Oscar's side, as a symbol for a whole industry he respects and belongs to. That is as far as he goes. Don't mess with the awards. Don't mess with the Academy. Don't mess with Hollywood.

This antagonism between Frankie and the rest of the cast is not present in the novel, where all characters are more rounded. Hymie, the rest of the nominees, and even Frankie's young wife, are aware of Oscar campaigning. Many of them are as manipulative and despicable as Frankie. Furthermore, his wife leaves him for Hymie in a clear sign of betrayal. The reputation of the Academy and the Oscar statuette are intact in the novel, as in the film. But

\footnotetext{
${ }^{13}$ The film's duration is 119 minutes.

${ }^{14}$ The chapter's titles are the different days in a progression starting on February 27, leading up to April 17. Needless to say, it does not cover day by day, but the progression marking important events in that chronology.

FRANKIE. Thank you for this party, Kenneth.

KENNETH. It's not necessary for me to listen to this slice of humility. Is it, Frankie?

You don't think my attitude towards you has changed, do you? I still consider you one of the most despicable men I've ever encountered.

FRANKIE. Why go into so much trouble for a bitter enemy?

KENNETH. I I not at all certain I can put it in terms you'd grasp.

FRANKIE. Then tell it like a giant golden book. I think I can cut it.

KENNETH. It has to do with pride and craft, Frankie, with identification and the industry.

FRANKIE. I didn't know this was a testimonial dinner.

KENNETH. Easy enough to be flippered. But I've been in the motion picture business for 37 years, and this smear that's being aimed at you, it's roil on the Academy Awards as well. And despite your smears, Fane, the Oscars mean a great deal to me, and to many of us in the industry. They are a symbol we don't like to see them tarnished.

I find myself repelled and repulsed by you, but you are getting us a fairly raw deal, and this party you see, we won't stand for it.

FRANKIE. I think my line is thanx for nothing.

KENNETH. I'm sure you think that's your line.
} 
the adaptation goes further by presenting composed and righteous members of Hollywood, a community in which a narcissistic and manipulative character like Frankie does not belong.

\section{Cameo-casting the Hollywood Mirage}

Part of the appeal of the film is its A-list casting for cameo roles, which adds to the intertextual illusion. More than $\$ 1,000,000$ from the $\$ 2,030,000$ budget was spent in fleeting star appearances. ${ }^{16}$ The production had to capitalize on this mirage to create its Hollywood illusion. The salaries paid to these figures were way above those paid to the main roles in the film. ${ }^{17}$ The cameo-cast included Nancy and Frank Sinatra - as the award winner, Bob Hope as the emcee, Merle Oberon, Hedda Hopper, Edith Head, and even art director Hal Pereira, among others. Rita Hayworth was also tempted to join the party, but declined the offer after long negotiations over requirements such as specific make-up artist and hair stylist. ${ }^{18}$

Hedda Hopper's celebrated final appearance is memorable. Besides being a former actress, she was a powerful gossip columnist at the time, regarded as an A-list celebrity, and an opinion-maker feared by many. In the novel she - as well as Louella Parsons - is mentioned as one of those prestige Hollywood players who planted rumor of Frankie's upcoming nomination. Hopper frequently collaborated with Public Relations consultants to shape the image of their represented stars. Public Relations' specialist Warren Cowan claims to be the first one to have articulated an Oscar campaign — with his partner Henry Rogers - when Joan Crawford was labeled "box-office poison" in a survey of exhibitors in the United States. According to him, Hopper played a significant role by planting rumors of Crawford's nomination. ${ }^{19}$ The publicist is convinced that such maneuvers helped the actress win the Oscar for Mildred Pierce (Warner Bros, 1945). ${ }^{20}$ Their firm, Rogers \& Cowan, also makes it to the book when Frankie threatens to change publicists. ${ }^{21}$ In the film, Hopper's appearance gives a glimpse to how Hollywood articulates stars' publicity, when she bumps into Frankie Fane dinning with an actress, hoping to spread rumor of romance to boost their profiles. The interesting resemblances in these stories add more layers to the inter-textual capacities of

${ }^{16}$ Some of the salaries: Hedda Hopper $\$ 200,000$, Edith Head $\$ 107,000$, Bob Hope $\$ 550,000$ Frank Sinatra \$100,000 and Nancy Sinatra \$10,000. Production files for The Oscar, Special Collections, Margaret Herrick Library.

${ }^{17}$ Memo, September 15, 1965. Production files for The Oscar. Special Collections, Margaret Herrick Library.

$\begin{array}{lll}\text { Jill St. John } & \$ 1,500 \text { per day } & \text { Total: } \$ 9,000 \\ \text { Stephen Boyd } & \$ 15,625 \text { per week } & \text { Total: } \$ 125,000 \\ \text { Tony Bennett } & \$ 4,000 \text { per week } & \text { Total: } \$ 40,000 \\ \text { Elke Sommers } & \$ 7,500 \text { per week } & \text { Total: } \$ 75,000 \\ \text { Eleanor Parker } & \$ 15,000 \text { per week } & \text { Total: } \$ 30,000 \\ \text { Milton Berle } & \$ 7,500 \text { per week } & \text { Total: } \$ 75,000 \\ \text { Edie Adams } & \$ 1,667 \text { per day } & \text { Total: } \$ 10,000\end{array}$

${ }^{18}$ Memo from Wally Westmore to Frank Caffey, May 25, 1965. Production files for The Oscar, Special Collections, Margaret Herrick Library.

19 "Planting" is a common PR strategy in which publicists fed rumors for journalists to spread a story about their clients, helping re-work their image.

20 "Publicist Warren Cowan on working on his first "For Your Consideration" Oscar campaign for Joan Crawford's Mildred Pierce," Archive of American Television, 3:35, interview conducted by Reba Merrill in Los Angeles, CA on May 5, 2001, http://www.emmytvlegends.org/interviews/people/warren-cowan\# .

${ }^{21}$ Sale, The Oscar, 321. 
Hopper's participation. Nevertheless, in the film, she is not directly connected to Oscar campaigning or PR lobby, drifting away from potential thoughts of corruption.

Hesitant about promoting a movie before seen it finished, Hopper was supposed to join the promotional caravan on February $4^{\text {th }}$. Her death on February $1^{\text {st }}$ cut loose that agreement. Her last few minutes on the screen did not go unnoticed. "There was an affecting moment at the movie premiere of Joseph E. Levine's 'The Oscar' when the late Hedda Hopper moved into camera range with Stephen Boyd and Jean Hale. Gorgeously gowned and with queenly mien, the columnist-actress delivered her punch lines to the hushed audience at the Egyptian Theatre. It was a climax that Hedda, the old pro, would have loved." 22 Hedda Hopper as well as Edith Head built brands out of their names that made them accessible to audiences beyond their backstage-roles.

Casting Bob Hope as the host was not a minor achievement considering that he was the face of the ceremony 15 times by $1966 .{ }^{23}$ Likewise, Edith Head's mediatized role as a costume designer for Paramount, and as the fashion consultant for the ceremony, made her an ideal figure for promotional purposes and inter-textual liaisons. Not to be forgotten that Head had side projects such as books, her fashionscope show, fashion columns in magazines, in addition to her constant media appearances as one of Paramount's iconic representatives. Furthermore, Head's celebrity status was such that the studio sent her instead of the leading actresses on the promotional tour for the film. The famous designer was modest about her onscreen role: "There's nothing more frightening than an amateur,"- she said — "I think an untrained voice is embarrassing. And I hope I don't look like a frightened school teacher."24

Head's brief participation in the film brings several layers to the text. First and foremost, she portrays the head costume designer at Paramount when she is working as a costume designer for the film in real life. In addition, the movie revolves around the Academy Awards, a celebration to which Head officiated as fashion consultant since 1953. In her capacities, she did not only coordinate the looks of celebrities, but even created gowns for the ceremony in some cases, and officiated as a fashion commentator for radio broadcastings of the event. Elke Sommers' character working at the costume department gives a glance of Edith Head's Hollywood-life.

This star-studded and overpaid cast supports how the production prioritized the inter-textual capacities of the narrative, by blurring the border between reality and fiction. Head's cameo role in the movie - as Hopper's - was minimal, and contributed no significant value to the narrative beyond adding a layer to the promotional appeal of real Hollywood.

\section{Promotion in Motion}

The intentions to rely on the Academy Awards for promotion are evident from the very first paragraph of the preliminary production information and synopsis. Oscar is on the spotlight, and so evidences these excerpts from a release, dated July 26, 1965.

The Oscar, a 13 1/2-inch golden statuette weighing under seven pounds, has grown to international stature in the 38 years since May 4, 1927, when it came into being as a symbol of the ultimate in

\footnotetext{
${ }^{22}$ Florabel Muir, "The Hollywood Beat, Wichita Falls," Texas Record News, Feb. 23, 1966.

${ }^{23}$ Hope was host for the Academy Awards a total of 18 times.

${ }^{24}$ Gloria Ohliger, "Edith Head on Fashion: Look Alikes in Bathtub!," The Washington Daily News,
} Feb. 2, 1966. 
achievement in the arts and sciences of the cinema. No single event, except the crowning of a royal head or the inauguration of an American president, commands the world interest of the Academy Awards Presentation- Oscar night. This year, Monday April 5, throughout the United States 80 million television sets were tuned in for the ceremonies, names of the Best Actor and Actress winners made headlines in newspapers throughout the world, and the details of the glamor and excitement of the event filled the pages.

Incredible as it may seem in the light of this, "The Oscar" is the first motion picture to tell the story of an Oscar race, the story of one man's climb from anonymity to the uneasy aisle set of an Oscar nominee on Oscar night. The film for the first time will tell the story of what it is like to a star to win and to lose 0 and what the golden symbol means in the industry. The story is told against backgrounds of infinite specific authenticity, presenting a unique "insiders" view, showing fictionally what one amoral man will do to win an Oscar, and factually, what moral men and women with loyalty and pride will do to protect its prestige and untarnished record of incorruptibility.

$[\ldots]$

The beautiful women in the film, Elke Sommer, Eleanor Parker, Jill St. John and Edie Adams, will be stunningly costumed by Edith Head, including their glamour gowns for scenes of Oscar night.

[...]

"The Oscar," the motion picture itself and the artists working on and in it, will one day be candidates for Oscars, so as filming begins it seems timely to chalk up the score to date: that is, 63 nominations and 15 Oscars. $[\ldots]^{25}$

Several promotional tie-ins were recommended to local exhibitor, as strategies to promote the film. Some were standard practices such as arranging deals with local bookstores, department stores and libraries to promote Richard Sale's novel. Travel agencies and airlines were invited to join by offering trips to Hollywood under the tagline: "See the fabulous world of Hollywood as it's never been seen before in 'The Oscar'-now at the State Theatre. Fly to Hollywood tomorrow aboard airlines." Other affordable option to capitalize on the star-studded cast was placing cutout large paper stars displaying the faces of the "big names" in the picture on store windows. But maybe the most interesting tie-in was related to the female audience and fashion, offering Oscar winning Hollywood designer Edith Head for local promotion, and fashion shows. "These fashions are big news to women everywhere and are certain to interest and excite the fashion editor of your local newspaper. Contact her today and arrange to have Mat EXP-1 planted on the fashion page along with credit for your theatre and playdate. These fashions can also open the way for you to a first class promotion with local women's store or specialty shop, including a special fashion show keyed to Hollywood utilizing stills and posters from the picture." 26

By 1966, Head was conducting several live appearances across the U.S. presenting Hollywood fashion shows at department stores. Her role as a fashion consultant for the show was explicitly underlined in several articles about the film, creating the much-wanted link to the ceremony. "The famous designer expects to be back in Hollywood in time to serve as fashion consultant for the Academy of Motion Pictures awards night in April." ${ }^{, 7}$ She was, next to Bob Hope, the strongest connection to exploit in relation to the Oscars, and Paramount did not hesitate moving in that direction.

\footnotetext{
${ }^{25}$ Preliminary production information and synopsis, July 26th, 1965. Production files for The Oscar. Special Collections, Margaret Herrick Library.

${ }^{26}$ Publicity material for The Oscar, Core Collections, Margaret Herrick Library.

${ }^{27}$ Ligaya Fruto, "Edith Head Urges Women to Revolt Against 'Ridiculous' Fashion," Honolulu StarBulletin, Mar. 2, 1966.
} 


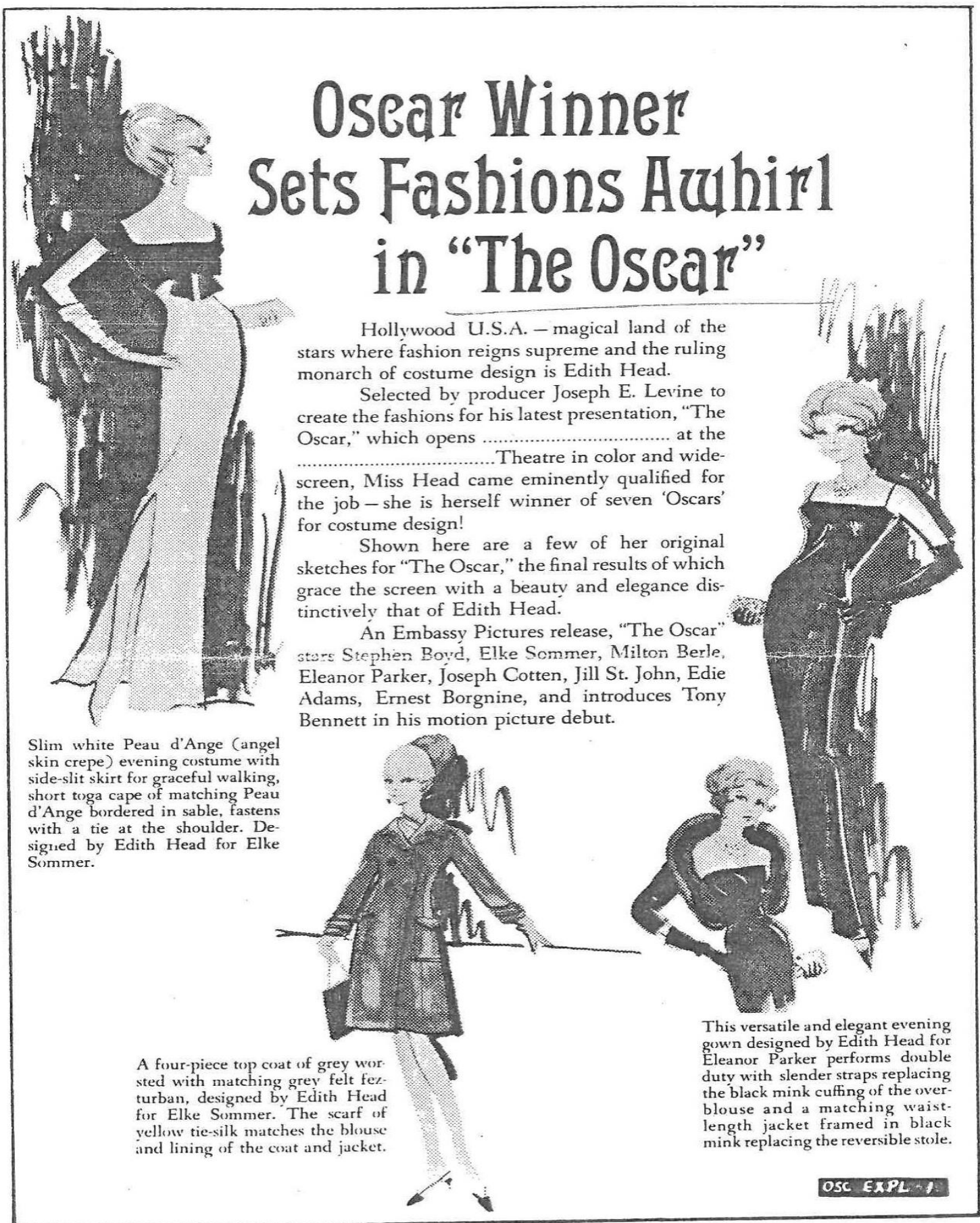

Copyright $\odot 1965$, Embassy Pictures Corp. Permission granted for Newspaper and Magazine reproduction. (Made in U.S.A.

Joseph E. Levine presents

THE OSCAR

A Green-Rouse Production. An Embassy Pichures release IN COLOR

Fig. 1: Image courtesy of the Publicity files for The Oscar, Core Collection, Margaret Herrick Library. Available under fair use. 
Despite her few seconds on screen, Edith Head — together with Stephen Boyd - took off on a promotional tour for the film, by press agent Bill Doll. Visiting Boston, Philadelphia, Detroit, Dallas, Washington, New York City, and Atlanta between January $30^{\text {th }}$ and February $11^{\text {th }}$. Elke Sommers and Elenor Parker joined them for a press conference at the Sheraton, in Boston. The visits were focused on gathering press and opinion makers to spread the word before the grand premiere. Besides screenings, press conferences and individual interviews, press luncheons were organized. ${ }^{28}$

As expected, Head took over the promotion of the film in her role as costume designer, making good use of her constructed public persona and public relations skills. The fashions of the Oscars were put in the forefront of the promotional campaign. ${ }^{29}$ The strategy paid off, and soon articles were flooded with comments such as "Edith Head's costumes on all the beautiful women are a major part of why The Oscar is such a good movie," or "you land on the moon some day, you may be wearing a costume by Edith Head." 30 She would also go into detail about the construction of characters through wardrobe in comments such as "The Oscar' presented some special design problems. In the picture there are four major female roles: the sophisticated leading lady, the young glamorous girl, the kook and the sexsymbol." 31 These digressing discussions helped promote her parallel activities as a stylist, author, and media personality; setting the ground for promoting her upcoming book, How to Dress for Success. "“If I didn't like an actress, I could kill her off in a single scene,' said Edith Head with deadly calm."-Published The Boston Globe. ${ }^{33}$ That capacity of empowering women through style enforced her new role to the public. Now Edith Head dressed not only characters, but could also transform women in real life. In helping the transition from costume designer to stylist, and taking advantage of this media exposure, Edith Head took the chance to flaunt her opinions about fashion. "You don't think I dressed Edie Adams in white plastic boots and pink polka dots because I like them, do you? [...] I don't think they [miniskirts and plastic dresses] are fashion. I think they are purely caricatures. They are making fun of fashion." 34

Not only the average female moviegoers were interested in the film's fashion. Elke Sommers' contractual demands listed: first class transportation between Germany and Los Angeles, reasonable paid excess baggage and the right to buy any clothes made for her at a $35 \%$ of cost. ${ }^{35}$ She supervised the creation of her outfits closely, insisting on having the sketches delivered to Germany in advance, calling Edith Head herself on collect to discuss any potential modifications. ${ }^{36}$ The actress took advantage of the deal, and bought outfits and

\footnotetext{
${ }^{28}$ Letter from Eddie Salomon to Mr. Frank Caffey, January 17, 1966. Production files for The Oscar, Special collection, Margaret Herrick Library.

${ }^{29}$ Interestingly, in the film titles and production files credited her for the creation of the gowns onlythe same role she had at the Academy Awards. The rest of the women's wardrobes were responsibility of Glenita Dinneen; the furs are credited to Frank Somper.

${ }^{30}$ Yvonne Petrie, "Up...Up...Up...and Away!," The Detroit News, Feb. 13, 1966.

${ }^{31}$ Patricia Mc Cormack, "Fashion Extremes take 'Last Fling' Says Edith Head," The Trentonian, Mar. $2,1966$.

${ }^{32}$ Edith Head, How To Dress for Success, (New York: Abrams, 1967).

33 Jane Pierce, "Off With Their Head? Never!," The Boston Globe, Feb. 18, 1966.

${ }^{34}$ Don Safran, Show Biz, Dallas Times Herald, Jan, 231966.

${ }^{35}$ Memo. Production files for The Oscar. Special Collections, Margaret Herrick Library.

${ }^{36}$ Interoffice communication from F.C.Richardson to Mr. Caffey, June 9, 1965. Production files for The Oscar, Margaret Herrick Library.
} 
accessories for total of $\$ 5,795.30 .{ }^{37}$ Elke's interest in the costumes was also used for publicity, and it soon resonated in the media throw multiple articles. "...Edith Head is giving her all, and her all is the best in town, to cover practically all of Elke Sommer in "The Oscar" with 21 costume change," said Mike Connolly in the Hollywood Reporter. ${ }^{38}$ "Right now Elke is busy on much more feminine pursuits. She's fitting for the 21 Edith Head creations she will wear in "The Oscar"-read The New York and Brooklyn Daily. She played along, kindly declaring: "I have never been dressed so beautifully in a movie." 39 Her shopping spree reflects how satisfied she was with the creations.

The promotional tour built up to the international gala premiere at the Egyptian Theatre on February $15^{\text {th. }}$ Just like at the Academy Awards' galas, carloads of stars "arrived in all sorts of outfits, from floor-length mink to multi-colored hair." ${ }^{40}$ Greeting them as they came on to the red carpet was no other than Army Archerd, Variety columnist and TV emcee, popularly known for greeting the stars at the Academy Awards ceremonies. The producers gathered 14 original Oscar-statuettes, on loan from several winners, and displayed in the hall. ${ }^{41}$ Some of the famous guests posed for the press holding the precious statuette. Considering the prohibition of using Oscar for promotion, it is interesting to reflect upon the legal aspect of displaying these at the premiere. The Academy was not going to provide statuettes for this purpose. Furthermore, using fake statuettes would have been a copyright infringement. This maneuver helped circumvent those regulations, as they were private property. Moreover, by having the owners place them on a table, the producers were not explicitly doing any promotional activity. Similarly, they were not responsible for celebrities picking them up to pose for the cameras, or journalists publishing the pictures. So, presumably, the production was not directly using Oscar's image to promote the film.

Another promotional strategy was announcing the film in their press releases as a holder 15 Oscar-wins and 63 nominations. "When casting a motion picture revolving around the annual Academy Awards, it was fitting that performers and personnel who have won or even nominated should be sought out."-Echoed Herald-Examiner's journalist George Jackson. ${ }^{42}$ The impressive number was the result of the joint previous achievements of those participating on- and off-camera. This seductive ad-line did not resist a close analysis, despite its fancy portrayal of the film. Only Edith Head would bring to the production more than 27 Oscar nominations and 7 wins. Equally, art director Hal Pereira holds 1 win and 19 nominations. High numbers of Oscar's nominations and awards might have been a common note for most Paramount productions, considering that Edith Head was head of costume design for most of the films coming from that company.

Keeping up the expenditure in grandiloquent promotional stunts, the production threw a publicity party for the completion of the shooting. Paramount and Las Vegas Riviera Hotel

${ }^{37}$ Elke Sommers- Wardrobe from "The Oscar" to be purchased. Production files for The Oscar. Special collections, Margaret Herrick Library.

${ }^{38}$ Mike Connolly, Rambling Reporter, The Hollywood Reporter, July 23, 1965.

39 "Cover Dixie like the Dew," The Atlanta Journal, Aug. 271965.

${ }^{40}$ Eddy Jo Bernel, "Star Twinkle in Gay Premiere of 'The Oscar'," Los Angeles Herald-Examiner, Feb. 16, 1966. A-3

${ }^{41}$ See Eddy Jo Bernel, "Star Twinkle in Gay Premiere of 'The Oscar'," A-3.

Some of the awards belonged to: Walter Brennan, Van Heflin, Bob Hope, Mercedes Mc Cambridge, Ray Milland, Donna Reed, Frank Sinatra, Ernest Borgnine, Red Buttons, Ed Begley, Jane Darwell and James Dunn.

${ }^{42}$ George H. Jackson. “A Natural-Winners in 'Oscar',” Herald-Examiner, Feb. 5, 1966. 
paired up to host 150 journalists from all over the country. ${ }^{43}$ The festivity took place at the Versailles room, and singing star Tony Bennett-who played his first role as an actor in the film - entertained the guests by performing a set of 20 songs. The party was captured on a 45 minute TV-special for Mike Douglas syndicated show, with Milton Berle as a co-emcee. For the logistics, the production hired a service from The American Flyers' Charter (Electra Jet), joining Los Angeles and Las Vegas in a one-hour flight. The aircraft was scheduled for departure on October 7, 1965 at 3 P.M from LAX. A Western Airlines Charter (Electra Jet) was scheduled to bring all passengers back from Vegas on October $8^{\text {th }}$ at 1 P.M. sharp.

Despite the allure of the awards, the marquee of stars, and the intense promotion, the film was received with mixed reviews. Those positive ones served-mostly-as channels to communicate press release lines, playing upon fantasies of Hollywood exposure. Likewise the promotional campaign, journalists flirted closely with Oscar associations. Creating expectations for a real close-up inside view, these articles described the film as better than touring Hollywood and its studios, as for it "gives one a real inside look at the cinema capital and its people," and it "takes viewers behind the scenes of the industry." Not least by emphasizing the star-cast, describing it as a "colorful Hollywood star junket, one of the largest Filmland caravans of its kind." ${ }^{44}$ Clearly promising more than what the film could deliver.

As a counterpoint, negative articles did not refrain in their appraisals: "It is hard to figure what has happened to the people in Hollywood - what weird sort of suicidal impulse has taken possession of them,"- - one wondered. ${ }^{45}$ "[W] hat possible excuse there is for itbeyond obvious commercialism"-assertively observed Life's Richard Schickel, further pontificating: "the vulgarity and stupidity with which its producers approach The Oscar is so blatant and moronic that one's initial rage a the naked corruption of their motives soon turns to helpless laughter." $" 46$

Some blamed its failure on the adaptation, speculating around Hollywood's self-censorship: "The Oscar ceremonies, after all, represent Hollywood's finest hour to many millions of people both within the industry and outside of it, and the word may have been implied, if not directly stated, 'Don't knock it, kid.' The result, unfortunately, is a vitiated, adulterated motion picture that does little justice to either its material or its producers." ${ }^{47}$ Others perceived the strategy as merely unacceptable: "What makes 'The Oscar' most distressing is that it boldly equates at just this time a sleazy fiction of attempted engineering of the Academy voting and the bestowal of Academy Awards." ${ }^{48}$ Or merely opted for unveiling the tricks, warning the audience: "[t]he Oscar reveals nothing of Hollywood or its awards; it merely exploits them., 49

\footnotetext{
${ }^{43}$ Series of correspondence between several parties for logistics. Production files, special collections, Margaret Herrick Library.

${ }^{44}$ Kate Cameron, “Bitter Drama Looks Inside Hollywood,” Daily News, Mar. 5, 1966.

George H. Jackson, A Natural-Winners in 'Oscar.'

“Star Junket coming, with 'Oscar' Figures,” Dallas Times Herald, Jan. 20, 1966.

45 Bosley Crowther, “Is Hollywood Killing Iself?” Newport Times, Mar. 13, 1966.

${ }^{46}$ Richard Schikel, Untitled, Life, Mar. 25, 1966.

${ }^{47}$ Leo Mishkin, "'The Oscar' Serves as Buildup."

${ }^{48}$ Bosley Crowther, "Is Hollywood Killing Iself?"

${ }^{49}$ Arthur Knight, Untitled, SR, Mar. 12, 1966.
} 
Unifying and categorizing reception for this film is no easy task. With conflicting reviews, leaning towards negative reception, there is only one certainty: The Oscar hit a nerve, and triggered strong opinions.

\section{Conclusions}

Just like the Academy Awards, The Oscar managed to gather a long list of celebrities and carry thousands of pages of publicity. Not surprisingly, the film got only two Oscar nominations, and - just like Frankie Fane - did not win. Expectedly, the nominees were Edith Head, for best costume design; and Hal Pereira, Arthur Lonergan (art directors), Robert R. Benton and James W. Payne (set decorators) for best art decoration-color. ${ }^{50}$

Despite not being financed or officially linked to the Academy of Motion Pictures Arts and Sciences, the film intertwines elements of fiction and reality in order to add up to that illusion. The production of such satellite text to profit from popular demand evidences the Oscars' cultural significance for at least half a century. Relying on cameo roles, and blurring boundaries of fiction and reality through stock footage added up to the illusion of a revealing narrative based in facts rather than fiction. Arguably, the use of the Academy Awards in the adaptation was nothing but a mere call to capitalize on the large success of the Oscarcast. ${ }^{51}$ The film could fully stand without it by ending the story with Frankie's contract release. However, it would have only account for yet another story about the rise and fall from fame with no further promotional potentials.

The copyrighted status of the Academy Awards' ceremony and the Oscar statuette posed limitations for promoting the film. Yet, several marketing and public relations' tricks pulled out by the publicity department worked efficiently without jeopardizing the relations with the Academy. Unable to officially use the Oscar for promotion, producers took advantage of all legal grey zones - not least considering that the movie carries the award's name in its title. Edith Head was a key player for the film's promotion. ${ }^{52}$ Her association with the Academy Awards surely was an asset for the production, and her cameo role was the perfect excuse to embark on the tour. In addition, she used the promotion of the film to her advantage, using the costumes to talk about the fashion dos and don'ts that would help her increase the sales of her spin-offs, and boosting her independent career.

Stripped from any association to the Academy Awards, the movie would not have had the powerful promotional assets to propel its publicity. A reason for its poor reception might rely on the incongruence between a larger-than-life campaign, triggering unfulfilled promises about a behind-the-scene Academy Awards' film that fails to deliver. The vast amount of casted celebrities were attracted by the shimmering effect of the Oscars, as so were audiences. Nevertheless, the film's weaknesses rose above the glare of that Hollywood veneer.

\footnotetext{
${ }^{50}$ Academy of Motion Pictures Arts and Sciences, http://awardsdatabase.oscars.org/ampas_awards/DisplayMain.jsp?curTime=1394770123130

${ }^{51}$ Word commonly used to refer to the telecast of the Oscar show.

${ }^{52}$ It is important to pinpoint that Head is credited in the film for designing only the gowns. Production files and sketches also support this, as the wardrobe team list other people in several roles in charge of it. Nevertheless, once taken on the promotional tour, Head served better to deliver the Oscar illusion.
} 


\section{Bibliography}

Chace, Reeve. The Complete Book of Oscar Fashion. London: Reed Press, 2003.

Dayan, Daniel and Elihu Katz. Media Events: Live Broadcasting of History. Cambridge: Harvard University Press, 1994.

English, James F. The Economy of Prestige: Prizes, Awards, and the Circulation of Cultural Value. Cambridge: Harvard University Press, 2005.

Frost, Jennifer. Hedda Hopper's Hollywood: Celebrity Gossip and American Conservatism. New York: New York University Press, 2011.

Head, Edith. How to Dress for Success. New York: Abrams, 1967.

Head, Edith. The Dress Doctor. New York: Harper Collins Publishers, 1959.

Holden, Anthony. The Oscars: The Secret History of the Academy Awards. London: Warner Books, 1994.

Jorgensen, Jay. Edith Head: The Fifty Year Career of Hollywood's Greatest Costume Designer. New York: Running Press Book, 2010. 336-339.

Klinger, Barbara. "Digressions at the Cinema: Reception and Mass Culture." Cinema Journal, Vol. 28, No. 4 (Summer, 1989): 3-19. Accessed April 29, 2013. http://www.jstor.org/stable/1225392

Levy, Emanuel. And the Winner is... The History and Politics of the Academy Awards. Michigan: Ungar, 1990.

Sale, Richard. The Oscar. New York: Simon and Schuster, 1963.

Sanders, Richard, ed. Oscar Style: Seventy Five Years of Glamour, Glitter and Glory. New York: People Books, 2003.

Sternheimer, Karen. Celebrity Culture and the American Dream: Stardom and Social Mobility. New York: Routledge, 2011.

Wiley, Mason, Damien Bona, and Gail MacColl. Inside Oscar: The Unofficial History of the Academy Awards. Kent: Columbus Books, 1986.

\section{Newspapers}

Bernel, Eddy Jo. 'Star Twinkle in Gay Premiere of 'The Oscar'." Los Angeles HeraldExaminer, Feb. 16, 1966. A-3 
Cameron, Kate. “Bitter Drama Looks Inside Hollywood.” Daily News, Mar. 5, 1966.

Connolly, Mike. Rambling Reporter. The Hollywood Reporter, July 23, 1965.

Crowther, Bosley. "Is Hollywood Killing Itself?" Newport Times, Mar. 13, 1966

"Cover Dixie like the Dew," The Atlanta Journal, Aug. 271965.

Fruto, Ligaya. "Edith Head Urges Women to Revolt Against 'Ridiculous' Fashion," Honolulu Star-Bulletin, Mar. 2, 1966.

Jackson, George H. A Natural-Winners in 'Oscar.' Los Angeles Evening \& Sunday Herald Examiner, Feb. 5, 1966.

Mc Cormack, Patricia. "Fashion Extremes take 'Last Fling' Says Edith Head," The

Trentonian, Mar. 2, 1966.

Mishkin, Leo. "'The Oscar' Serves as Buildup,” The Morning Telegraph, March 5, 1966.

Muir, Florabel. "The Hollywood Beat, Wichita Falls.” Texas Record News, Feb. 231966.

Ohliger, Gloria. "Edith Head on Fashion: Look Alikes in Bathtub!" The Washington Daily News, Feb. 2, 1966. Petrie, Yvonne. "Up...Up...Up...and Away!" The Detroit News, Feb. 13, 1966.

Pierce, Jane. "Off With Their Head? Never!” The Boston Globe, Feb. 18, 1966.

Safran, Don. Show Biz, Dallas Times Herald, Jan, 231966.

Scheuer, Phillip K. "A Behind-Scenes View of What Makes 'Oscar' Run," Los Angeles

Times, September 2, 1965.

Schikel, Richard. Untitled, Life. Mar. 25, 1966.

"Star Junket coming, with 'Oscar’ Figures,” Dallas Times Herald, Jan. 20, 1966.

\section{Filmography}

The Oscar (Embassy Pictures/Paramount Pictures, 1966)

Mildred Pierce (Warner Bros, 1945)

\section{Online Multimedia}

Cowan, Warren. "Publicist Warren Cowan on working on his first "For Your Consideration" Oscar campaign for Joan Crawford's Mildred Pierce." Archive of American Television, 3:35. Interview conducted by Reba Merrill in Los Angeles, CA on May 5, 2001. http://www.emmytvlegends.org/interviews/people/warren-cowan\# .

\section{Biography}

Elizabeth Castaldo Lundén is a PhD Candidate at the Department of Media Studies at Stockholm University. She holds an MA in Cinema Studies from Stockholm University, graduate studies in Psychology, Marketing and Public Opinion, and a BA in Public Relations from U.A.D.E, Argentina. She worked in Public Relations for the Entertainment and Advertising industries for more than 10 years. She is currently writing her dissertationOscar's Red Carpet: From Local to Global (A Media History) under supervision of Professor Jan Olsson.

E-mail: elizabeth.castaldo.lunden@ims.su.se 